\title{
2D- and 3D-cell culture
}

\author{
A. I. Khoruzhenko
}

Institute of Molecular Biology and Genetics NAS of Ukraine

150, Akademika Zabolotnogo Str., Kyiv, Ukraine, 03680

a.i.khoruzhenko@imbg.org.ua

\begin{abstract}
The cultivation of mammalian cells in three-dimensional conditions acquires a priority in a variety of biomedical applications. In the areas of toxicology and anticancer drug development it concerns a significant difference of responses to proapoptotic factors of the cells cultured in $2 D$ versus $3 D$ environment. Besides, the clear-cut differences have been found in cell polarity, cytoskeleton structure, distribution of receptors to wide range of hormones, growth factors, etc. in mammalian cells depending on culture conditions. It is resulted in different response of cultured cells to extracellular stimuli. Multicellular spheroids are regarded presently as the most convenient model of solid tumour growth in vitro. The cultivation of thyroid follicles, mammary acini and other structure units, maintaining initial tissue organization, allows studying the behavior, biochemical features and gene profile of differentiated cells. On the other hand, 3D cultures have some limitations in comparison with a well established monolayer culture. The advantages and disadvantages of each type of cultures and their application in biological and medical researches will be discussed in this review.
\end{abstract}

Key words: $2 D$ and $3 D$ cultivation, resistance, differentiation.

Brief overview of creating the method of cell culture. The method of cell culture is a powerful instrument of medical and biological studies. The first fundamental articles, devoted to the elaboration of this approach, were written as far as 100 years ago. The selection of cultivation conditions, which are standard nowadays (temperature, humid gas phase, aseptics technology, standardized cultural nutrient media), required significant efforts, which was reflected in the works of Lambert, Carrel, and others [1-4]. The very possibility of existence of living cells outside the initial organism was first shown by Loeb in 1897, at the time of the first successful attempt to transplant the skin fragments of a guinea pig embryo into agar, on coagulated serum and into the organism of an adult animal [2]. With time the source of obtaining cultures was not only the embryonic tissue, as cell cultures were isolated from different tumors as well [3]. The first

(c) Institute of Molecular Biology and Genetics NAS of Ukraine, 2011 cultures were obtained by placing the fragment of tissue into the plasma with subsequent formation of a fibrin clot or into the agar. This cultivation lasted at least 20 days [4]. The decisive importance was attributed to the fact that it was possible to isolate cell cultures not only from different tissues of the organism, but also from primary cultivated cells due to their passaging, as shown on secondary and tertiary cultures of thyroid gland, spleen, sarcoma cells [4].

It was practically at the same time that several laboratories discovered the ability of cells to have proliferation in the culture conditions. Another interesting fact was revealed in the observation that the cells of the nervous system of the frog embryo were capable of differentiating ex vivo, namely, they formed long nervous endings [4]. Besides, it was established in 1912 that cultivated mammalian cells; in particular, the cells of lymph nodes and bone marrow of a guinea pig are capable of producing antibodies [5]. 
The next stage of elaborating the method of cell culture was the attempt of isolating pure cell cultures of a certain type. Thus, primary cultures, consisting either of amoeboid cells or round cells [6], were isolated from the stroma of heart of the chicken embryo. Maksimov, who formulated the unitary theory of hematopoiesis and was the first to use the term "a stem cell", investigated human connective tissue by the method of cell culture [7].

Further application of the cellular material of chicken embryo allowed isolating primary cultures of different types of cells, while the application of cell cultures of rodents facilitated the application of established cellular lines [8]. The possibility of supporting established lines, originating from human tumor cells, was shown on the example of HeLa cells [9]. The classic studies of Hayflik revealed temporal limits of life of normal chicken embryo cells in the culture [10]. Further rapid development of the method of cell culture demonstrated its suitability not only for biomedicine, but also for studies in the sphere of pharmacology, ecology, and veterinary science.

Terminology. Prior to laying out the method of cultivation, let us present some most frequent terms according to Freshney's manual [11]. A tissue culture is a generic term that refers to both organ culture and cell culture. An organ culture is always meant to be the three-dimensional culture of disaggregated tissue, preserving some or all the histological specificities of the primary tissue; the cell culture is the culture, initiated from dispersed cells, isolated from the primary tissue, primary cultures or cell lines due to enzymatic, chemical or mechanical disaggregation. According to Adams's manual [12] the cell culture should be considered as primary one, when it is isolated directly from the organism; and its further cultivation allows obtaining cell lines, which are generally heterogeneous in their composition. Cloning, physical or other selection of cells from the cell line allows obtaining cell strains with specific properties [11, 12]. Histotypic cultures are the result of disaggregation of cellular material for restoration of three-dimensional tissue-like structure. Organotypic cultures are similar to histotypic ones, but their isolation requires the application of several types of cells (a classic example is co-cultivation of epidermal keratinocytes and dermal fibroblasts) [11].

The sources of obtaining cell cultures. The cell cultures of mammals, including humans, are most widely used in the investigations in the biomedical sphere. Therefore, the main attention of this review will be paid to the abovementioned cultures. They are obtained both from the normal tissue and pathologically modified organs and tissues, including benign, malignant tumors, tissues with inflammation, disorder of metabolic processes, etc.

Primary cultures of cells, obtained from the tissue of the organism, have a number of advantages: firstly, this is direct origin from the cells of the primary organism and relative simplicity of obtaining two-dimensional primary cultures. The cultivation of mammalian cells in three-dimensional conditions while preserving initial tissue organization allows maximal approximation of experiment conditions to those of the organism. In medicine primary cultures are used to determine the karyotype and in some other investigations [13]. On the other hand, there are some limits of their application, including the need of the source to obtain cultures, a lower level of reproducing organisms; limited number of possible reduplication of the population for cells from the normal tissue. These problems may be partially solved by using cell lines, obtained from normal, benign or malignized tumor tissues, for the study in the mechanisms of malignant transformation of cells, trial of medical preparations, in particular, suppressors of tumor growth, revealing differences in physiological and biochemical indices of tumor and normal cells. The cells of lines are cultivated both in two-dimensional and three-dimensional conditions [14]. The known cell lines are widely used in research work, they are remarkable for a higher level of reproducibility in experiments compared to primary lines. It its turn, the application of cell lines has some limits. The phenotype and genotype of cultivated cells may differ considerably from those of the cells of the initial tissue. In particular, the populations of malignant tumour cells are heterogeneous in their composition; therefore, during cultivation there is selection of cells according to their capability to survive. Besides, the work with several cell lines is accompanied with the problem of their cross-contamination. The investi- 
gations, performed by a number of authors, demonstrated that only 23 among 40 most widely used cell lines of thyroid gland had a unique genetic profile. Some lines had common origin, while others were crosscontaminated by cells of other lines [15]. Cell lines are inapplicable for determination of individual sensitivity to medical preparations (chemotherapeutic, first of all).

The approaches to cultivation of cells of humans and mammals, their disadvantages and advantages. Organ cultures. The cultivation of small parts of tissue by the method of organ culture allows preserving the initial histological structure which provides considerable correlation with in vivo conditions. However, after several days of cultivation the process of necrosis is launched in the central zone of the explant, which is conditioned by insufficient access of oxygen and nutrients. With time this process spreads to periphery as well. Special means are elaborated to overcome this problem, ACUSYST-S chamber being among them [16]. The second approach presupposes the application of miniorganic cultures. Precise microscopic equipment allows decreasing the size of grained fragment of thyroid tissue to $0.5-0.9 \mathrm{~mm}$, besides, the content of oxygen is increased to $50 \%$ which promotes rapid reduction of the necrosis zone. Thus, the cultures of the normal tissue and malignant tumor of thyroid gland were obtained [17].

Monolayer cultures and cultures on floating substrates. The method of monolayer cultivation is widely used in biomedical studies, in particular, with the purpose of determining the mitotic potential of cells, change of their functional activity under the impact of specific factors, for comparison of physiological and biochemical characteristics of cells, obtained from normal and tumor tissues. Monolayer cultures of dermal fibroblasts are used for the analysis of human karyotype for diagnostic purposes along with the suspension culture of lymphocytes. However, this approach has a significant drawback. During the cultivation in twodimensional conditions the investigated cells lose their histological organization, which is finally reflected in their behavior and biochemical specificities. Besides, the polarization of cultivated cells is violated. First of all, it is true regarding epithelial cells, which have clearly differentiated functions of apical and basal membranes in vivo [18].
Some authors used the cells of thyroid gland as an example to demonstrate that the loss of follicular organization in conditions of the monolayer culture results in the loss of polarization of thyrocytes, considerable decrease in the ability to capture and transport iodine, disorder of intercellular contacts and connection to the basal membrane $[19,20]$. Similar modifications were observed for the cells of other organs and tissues, including mammary gland, kidneys, etc. [21, 22]. The cultivation in three-dimensional conditions was suggested to solve these issues. The cultures, in which cells are stimulated by relevant factor to form initial histolike structures, may be considered as an intermediate variant $[23,24]$.

Besides, the use of collagen or gelatin substrate for floating monolayer cultures allows preserving the polarization of cultivated epithelial cells [25]. For instance, the work [25] presents the data on asymmetry of localization of receptors to the thyrotropic hormone. The introduction of the latter to the cells, cultivated on collagen gel, attached to the surface of plastic, did not result in any observed effect on the cells. If the gel with cells is unfastened from the cultural surface, thyrocytes become sensitive to the effect of thyrotropic hormone.

Further elaboration of this approach led to the application of bicameral chambers, divided by the membrane - transwells. The example of cell cultures, obtained from normal and tumor tissues of different organs, demonstrates that cells preserve their polarity during their cultivation on transwells [26, 27].

Multicellular spheroids. Multicellular spheroids are often used to simulate tumor growth, especially in case of poorly differentiated tumors, further they are analyzed by biochemical, histological and immunohistochemical methods [28]. To obtain spheroids, the suspension of cells is placed into conditions, preventing the adhesion of cells to growth surface. An agarose layer or siliconized surface is most frequently used for this purpose. Similar to organ cultures, the limitation of this method of cultivation is insufficient access of oxygen and nutrients into central parts of the spheroid after it gets considerable size. Spheroid cultures are applied to analyze extracellular matrix due the similarity of spheroid cultures and solid tumors [30, 31]. Moreover, the application of spheroid cultures allowed revealing the difference in the interaction of 
papillary and follicular thyroid carcinoma cells with endothelial cells during the simulation of extravasation of tumor cells from the blood flow [32].

Cultivation in soft agar. Tumor potential of cultivated cells is often revealed by their capability to form colonies in soft agar. The essence of this test is the determination of the number of cells, capable of giving independent beginning to a new colony which is deemed to be the model of initial stages of metastases in the conditions of the organism. Then the suspension of investigated cells is placed into soft agar (the concentration of agarose is about $0.3 \%$ ) to secure independent growth of each cell. The efficiency coefficient of colony-formation is calculated after certain time of cultivation; for this purpose the ratio of the number of formed colonies and the number of introduced cells is expressed in percentage terms [33]. Regardless of the fact that the issue of the origin of metastases from one cell or from the colony of cells is yet to be discussed, this test is widely used in pharmacological studies of tumor suppressors [34]. Many authors demonstrated that the sensitivity of tumor cells, cultivated in soft agar, to proapoptotic agents has better correlation with the results, obtained in vivo, than the reaction of cells, cultivated in the monolayer.

Aggregates offollicles, acini, etc. In addition to the abovementioned, there is another approach to the cultivation of mammalian cells in three-dimensional conditions. It presupposes the application of "functional units" (follicles, acini, etc.) for the initiation of primary cultures with further preservation of the initial histological structure. For this purpose the follicles or acini are "enucleated" from the initial tissue using matrix-degrading enzymes and they are either placed on the non-adhesive substrate, or immersed into collagen gel (matrigel, etc.). It is possible to work with the suspension of thyroid follicles in conditions of the rotational culture [35]. However, if they are placed on the layer of agarose or siliconized plastic, it is possible to achieve the formation of floating aggregates, preserving the initial histological structure in many aspects. These cultures have significant advantages from the standpoint of both cell physiology and methodological approaches to the application of cultures in experiments. In the majority of cases the preservation of the initial structure of the tissue in culture conditions is re- lated to maintaining functional activity of the investigated cells. On the other hand, this methodological approach allows performing histological and immunohistochemical analysis of cultures regarding the presence and localization of certain antigens in the very cells and in the extracellular matrix. Its limitation is the alleged obtaining of sufficient amount of material from the tissues of the organism to initiate primary cultures. Similar to multicellular spheroids, the acquisition of considerable sizes delays the access of oxygen and nutrients into the central sites of the aggregate. The maintaining of cells in the differentiated state (like for other types of cultures) requires additional growth factors and hormones depending on the origin of cultivated cells. Besides, during enzymatic disaggregation of the tissue some structures are destroyed and unstructured parts may appear in the composition of floating aggregates. However, taking into consideration the abovementioned issues this approach allows studying the properties of cells in conditions, maximally approximated to in vivo state. Thus, we have shown that the cultivation of human and murine thyrocytes in conditions of monolayer culture leads to significant content of thyroglobulin in the cells, which is the main index of their functional activity. The immunochemical analysis revealed that in 10 days of cultivation in the monolayer culture only $30 \%$ of cells contain thyroglobulin, similar results were obtained during the investigation of cells, cultivated in the form of multicellular spheroids. Contrary to them, all the cells in the composition of follicle-like structures of floating aggregates of follicles demonstrate expressed positive immunohistochemical reaction to thyroglobulin. Moreover, the cells from the sites, which do not preserve follicle-like organization, did not contain thyroglobulin. Therefore, our studies revealed that cultivation of thyrocytes in the form of aggregates of follicles is closer to the conditions of the living organism than cultivation in the form of a monolayer or multicellular spheroids [36, 37].

The application of two- and three-dimensional cultures in biomedical studies. The problem of maintaining the differentiation of cells in the monolayer culture. The histological structure of tissues of the organism is closely related to the fulfillment of specific functions of the cells. The structure of intes- 
tines secures the processes of resorption of nutrients, alveoli are responsible for gas exchange, muscle tissue - for contractions, etc. The disorders in the functions of organs are very often accompanied by changes in the tissue organization. For instance, the substitution of the muscle tissue with connective tissue fibrils complicates muscle contractions, squamous metaplasia of thyrocytes impairs the function of the thyroid gland, the occurrence of atherosclerosis plaques impairs blood circulation, etc. Therefore, the simulation of different processes in ex vivo conditions requires the consideration of specificities of the initial tissue.

The application of monolayer cultures in the study of keratinocytes of skin of humans and mammals proved to be successful. It was possible not only to obtain reproducible cultures of cells, but also the impact of certain factors (change in the concentration of calcium, cultivation on the interface of liquid and gas phases, etc.) allows achieving the level of stratification of layers of keratinocytes, corresponding to that in vivo. Practically, the approach to obtaining of artificial analogues of skin (including the application of cultivated keratinocytes and fibroblasts) is based on the combination of methods of two- and three-dimensional cultivation, which is successfully applied in many laboratories [38]. It was shown that in conditions of a monolayer culture the endothelial cells contain von Willebrand factor, which is one of the markers of their differentiation, and are capable of secreting the extracellular matrix, partially reminding their matrix in vivo [39]. On the other hand, these conditions promote the impairment of the capability of smooth muscles to contract [40]. As shown above, the content of thyroglobulin in thyrocytes decreases sharply. Although in some cases the accumulations of thyrocytes, formed under the impact of thyrotropic hormone in monolayer culture, were considered to be follicle-like structures [41].

The sensitivity of cells to proapoptotic factors in conditions of two and three-dimensional cultures. Recent trends of medical and biological researches testify to the advantages of the cultivation of cells in three-dimensional conditions [42]. In 1997 Bissell's group received a number of well-founded data on the difference in the behavior of human breast carcinoma cells, cultivated in the form of two and three-di- mensional cultures. During the incubation of cells, growing in the three-dimensional culture, with antibodies to beta 1-integrin, breast carcinoma cells acquired non-malignized phenotype, lost the atypical form and changed the type of growth. However, this effect was not reproduced in the monolayer culture [43].

On the next stage this group revealed that during the three-dimensional cultivation the addition of antibodies to beta 1-integrin hinders the transmission of the intracellular signal from receptors of epidermal growth factor (EGF). On the other hand, the antibodies to receptor EGF inhibit the activity of beta 1-integrin. This reciprocal effect was not achieved in the conditions of two-dimensional culture [44]. The receptors to growth factors play a key role in the development of malignant tumors, and this is not the only conclusion of the investigation of carcinogenesis mechanisms, obtained using three-dimensional cultures. Usually during metastasis the cells produce enzymes, splitting the fibrils of extracellular matrix [45]. The inhibitors of these enzymes are sometimes used in the clinical practice. However, the model of three-dimensional cultures was used to demonstrate that even complete inhibition of matrix metalloproteinases, serine proteases, cathepsin and other proteases do not prevent the fibrosarcoma cells from migrating. Their protruded form becomes more round and due to amoeboid movement the cells keep "pushing" through the matrix fibrils. The behavior of these cells is the same after the subcutaneous injection to mice [46]. Moreover, Marshall et alt. demonstrated that during blocking of Rho-signaling pathway the cells lose their capability of amoeboid movement, independent from proteolytic enzymes. Thus, the three-dimensional model of cultivation was used to demonstrate the pathway of combined inhibition of metastasis of tumor cells [47]. It was revealed using fibroblasts that contrary to monolayer culture these cells grow faster in the threedimensional culture and become asymmetrical, similar to in vivo conditions [48].

Besides, the studies demonstrated the resistance of mesothelioma cells, cultivated in three-dimensional conditions, to TRAIL (TNF - related apoptosis- inducing ligand) in the complex with gemcitabine, while in the monolayer culture the cells showed their resistance to these agents $[49,50]$. Similar effect was observed 
during the investigation of the impact of the complex of Bortezomib and TRAIL as proapoptotic agents on lung carcinoma cells A549. After the introduction of these cells into the conditions of the monolayer culture the mentioned agents caused apoptosis, while in spheroid cultures the investigated cells were resistant to these factors, which correlates with the results, obtained on laboratory animals [51].

Conclusion. Summing up the abovementioned, it should be mentioned that each approach to the cultivation has both advantages and disadvantages. However, the focus of selecting the conditions of the cultivation should be placed at the initial histological organization of the investigated tissue. The introduction of cells into the strange conditions leads to the impairment of intracellular interactions, polarization, distribution of receptors of growth factors and hormones and makes its own input into the response of cells to the tested factors. Recently the time of cultivation in three-dimensional conditions is considered to be one of the main pathways during the investigation of the properties of cells in vitro [52-54]. Similar point of view is based on the statement that in vivo the cells in the organism are in the composition of three-dimensional structures, for instance, thyroid follicles. It promotes the implementation of specific functions by tissues and organs. However, usually the investigation of these cultures raises a number of the abovementioned methodological questions. On the other hand, in conditions of monolayer cultures the cells preserve many fundamental properties, inherent to them in vivo, including a part of antigens differentiation markers. Therefore, the most promising method is deemed to be the use of the combination of these two ways of cultivation during the investigation of adhesion, proliferation, migration, invasion, differentiation of cells and many other processes, occurring in the organism in norm and disease [55].

\section{А. И. Хоруженко}

Двух- и трехмерная культура клеток

Институт молекулярной биологии и генетики НАН Украины Ул. Академика Заболотного, 150, Киев, Украина, 03680

\section{Резюме}

Культивирование клеток млекопитающих в трехмерных условиях становится приоритетным в многочисленных биомеди- цинских приложениях. В области токсикологии и разработки противоопухолевых препаратов это связано со значительной разницей ответа клеток, культивируемых в двух-или трехмерных условиях, на проапоптотичные факторы. Кроме того, выявлены существенные отличия в поляризации клеток, структуре ичитоскелета, распределении рецепторов $\kappa$ иирокому спектру гормонов, ростовых факторов и т. д. в клетках млекопитающих в зависимости от условий культивирования. В конечном итоге, это проявляется в различной реакции культивируемых клеток на внеклеточные стимуль. Наиболее адекватной моделью роста солидных опухолей іп vitro сейчас принято считать многоклеточные сфероидь. Культивирование фолликулов щчитовидной железы, ацинусов молочной железы и других структурно-функииональных единии, сохраняющих исходную организацию ткани, позволяет изучать поведение, биохимические особенности и генетический профиль дифференцированных клеток. С другой стороны, трехмерные культуры имеют ряд ограничений по сравнению с широко используемыми монослойными культурами. Недостатки и преимуще -ства каждого типа культур, а также их применение в биологических и медицинских исследованиях являются предметом этого обзора

Ключевые слова: двух- и трехмерное культивирование, резистентность, дифференцировка

\section{A. I. Хоруженко}

Дво- і тривимірна культура клітин

Резюме

Культивування клітин ссавців за тривимірних умов стає пріоритетним у численних біомедичних застосуваннях. В галузі токсикологї і розробки протипухлинних препаратів цุе пов'язано зі значною різницею у відповіді клітин, культивованих за дво- або тривимірних умов, на проапоптичні чинники. Крім того, виявлено істотні відмінності в поляризації клітин, структурі циитоскелета, розподілі рецепторів до широкого спектра гормонів, ростових чинників і т. д. у клітинах ссавиів залежно від умов культивування. Зрештою, ие проявляється в різній реакиії культивованих клітин на позаклітинні стимули. Найадекватнішою моделлю росту солідних пухлин іп vitro наразі вважають багатоклітинні сфероїди. Культивування фолікулів шитоподібної залози, ачинусів молочної залози та інших структурно-функиіональних одиниць, щчо зберігають початкову організацію тканини, дозволяє вивчати поведінку, біохімічні особливості і генетичний профіль диференційованих клітин. 3 іншого боку, тривимірні культури мають низку обмежень порівняно з широко використовуваними моношаровими культурами. Недоліки й переваги кожного типу культур, а також їхнє застосування в біологічних $і$ медичних дослідженнях становлять предмет ичього огляду.

Ключові слова: дво- та тривимірне культивування, резистентність, диферениіювання.

\section{СПИСОК ЛИТЕРАТУРЫ}

1. Lambert R. A. The effect of dilution of plasma medium on the growth and fat accumulation of cells in tissue cultures // J. Exp. Med.-1914.-19, N 4.-P. 398-405.

2. Loeb L. On the growth of epithelium in agar and blood-serum in the living body // J. Med. Res.-1902.-8, N 1.-P. 109-115. 
3. Carrel A., Burrows M. T. Cultivation in vitro of malignant tumors // J. Exp. Med.-1911.-13, N 5.-P. 571-575.

4. Carrel A., Burrows M. T. Cultivation of tissues in vitro and its technique // J. Exp. Med.-1911.-13, N 3.-P. 387-396.

5. Carrel A., Ingebrigtsen $R$. The production of antibodies by tissues living outside of the organism // J. Exp. Med.1912.-15, N 3.-P. 287-291

6. Carrel A. Pure cultures of cells // J. Exp. Med.-1912.-16, N 2.-P. 165-168.

7. Danilov R. K., Gololobov V. G., Deev R. V. Aleksandr Aleksandrovich Maksimov - vydayushchiysya otechestvennyy gisto$\log$ (stranitsy zhyzni i nauchnoe nasledie) // Vestnik Rossiyskoy Voenno-Meditsinskoy Akademii.-2003.-2, N 6.-P. 54-60.

8. Earle W. R., Schilling E. L., Stark T. H., Straus N. P., Brown M. F., Shelton E. Production of malignancy in vitro. IV. The mouse fibroblast cultures and changes seen in the living cells // J. Natl Cancer Inst.-1943.-4.-P. 165-212.

9. Gey G. O., Coffman W. D., Kubicek M. T. Tissue culture studies of the proliferative capacity of cervical carcinoma and normal epithelium // Cancer Res.-1952.-12.-P. 264-265.

10. Hayflik K. L., Moorhead P. The serial cultivation of human diploid cell strains // Exp. Cell. Res.-1961.-25.-P. 585-589.

11. Freshney R. I. Culture of animal cells. A manual of basic technique $/ 4^{\text {th }}$ edition.-New York: Wiley-Liss, 2000.-600 p.

12. Adams R. L. P. Cell culture for biochemists.-Moskwa: Mir, 1983.-263 p

13. Park I. H., Arora N., Huo H., Maherali N., Ahfeldt T., Shimamura A., Lensch M. W., Cowan C., Hochedlinger K., Daley G. $Q$. Disease-specific induced pluripotent stem cells // Cell.2008.-134, N 5.-P. 877-886.

14. Grimm D., Kossmehl P., Shakibaei M., Schulze-Tanzil G., Pickenhahn H., Bauer J., Paul M., Cogoli A. Effects of simulated microgravity on thyroid carcinoma cells // J. Gravit. Physiol.-2002.-9, N 1.-P. 253-256.

15. Schweppe R. E., Klopper J. P., Korch C., Pugazhenthi U., Benezra M., Knauf J. A., Fagin J. A., Marlow L. A., Copland J. A., Smallridge R. C., Haugen B. R. Deoxyribonucleic acid profiling analysis of 40 human thyroid cancer cell lines reveals cross-contamination resulting in cell line redundancy and misidentification // J. Clin. Endocrinol. Metab.-2008.-93, N 11.-P. 4331-4341.

16. Velicky J., Sterzl I., Mandys V., Bednar J., Titlbach M., Niahodil $V$. Morphological changes in the human thyroid gland cultivated in continual flow system // Zhur. Mikrosk. Anat. Forsch.-1990.-104, N 5.-P. 788-796.

17. Bauer M. F., Herzog V. Mini organ culture of thyroid tissue: a new technique for maintaining the structural and functional integrity of thyroid tissue in vitro // Lab. Invest.-1988.-59, N 2.-P. 281-291.

18. Massart C., Gibassier J., Genetet N., Raoul M. L., Baron M., Le Gall F., Lucas C. Effect of lymphocytes on hormonal secretion by autologous thyrocytes cultured in monolayers // J. Mol. Endocrinol.-1996.-17, N 3.-P. 185-195.

19. Westermark B., Heldin N. E., Westermark K. Structural and functional properties of thyroid follicle cells in culture // Acta. Physiol. Scand. Suppl.-1990.-592.-P. 15-24.

20. Gartner R. Thyroid growth in vitro // Exp. Clin. Endocrinol.-1992.-100, N 1-2.-P. 32-35.

21. Kozlowski M., Gajewska M., Majewska A., Jank M., Motyl T. Differences in growth and transcriptomic profile of bovine mammary epithelial monolayer and three-dimensional cell cultures // J. Physiol. Pharmacol.-2009.-60, Suppl 1.-P. 5-14.
22. Rosines E., Schmidt H. J., Nigam S. K. The effect of hyaluronic acid size and concentration on branching morphogenesis and tubule differentiation in developing kidney culture systems: potential applications to engineering of renal tissues // Biomaterials.-2007.-28, N 32.-P. 4806-4817.

23. Mauchamp J., Mirrione A., Alquier C., Andre F. Follicle-like structure and polarized monolayer: role of the extracellular matrix on thyroid cell organization in primary culture // Biol. Cell.-1998.-90, N 5.-P. 369-380.

24. Pellerin S., Croizet K., Rabilloud R., Feige J. J., Rousset B. Regulation of the three-dimensional organization of thyroid epithelial cells into follicle structures by the matricellular protein, thrombospondin-1 // Endocrinology.-1999.-140, N 3.P. 1094-1103.

25. Chambard M., Verrier B., Gabrion J., Mauchamp J. Polarization of thyroid cells in culture: evidence for the basolateral localization of the iodide «pump» and of the thyroid-stimulating hormone receptor-adenyl cyclase complex // J. Cell Biol.-1983.-96, N 4.-P. 1172-1177.

26. Grande M., Franzen A., Karlsson J. O., Ericson L. E., Heldin $N$. E., Nilsson $M$. Transforming growth factor- $\beta$ and epidermal growth factor synergistically stimulate epithelial to mesenchymal transition (EMT) through a MEK-dependent mechanism in primary cultured pig thyrocytes // J. Cell Sci.2002.-115, pt 22.-P. 4227-4236.

27. Nilsson M., Husmark J., Nilsson B., Tisell L. E., Ericson L. E. Primary culture of human thyrocytes in Transwell bicameral chamber: thyrotropin promotes polarization and epithelial barrier function // Eur. J. Endocrinol.-1996.-135, N 4.-P. 469-480.

28. Chomyak O. G., Sidorenko M. V. Multicellular spheroids model in oncology // Exp. Oncol.-2001.-23, N 4.-P. 236-241.

29. Mueller-Klieser $W$. Multicellular spheroids. A review on cellular aggregates in cancer research // J. Cancer Res. Clin. Oncol.-1987.-113, N 2.-P. 101-122.

30. Nederman T., Norling B., Glimelius B., Carlsson J., Brunk U. Demonstration of an extracellular matrix in multicellular tumor spheroids // Cancer Res.-1984.-44, N 7.-P. 3090-3097.

31. Infanger M., Kossmehl P., Shakibaei M., Bauer J., KossmehlZorn S., Cogoli A., Curcio F., Oksche A., Wehland M., Kreutz R., Paul M., Grimm D. Simulated weightlessness changes the cytoskeleton and extracellular matrix proteins in papillary thyroid carcinoma cells // Cell Tissue Res.-2006.-324, N 2.P. 267-277.

32. Grimm D., Bauer J., Kromer E., Steinbach P., Riegger G., Hofstadter $F$. Human follicular and papillary thyroid carcinoma cells interact differently with human venous endothelial cells // Thyroid.-1995.-5, N 3.-P. 155-164.

33. Vuillermoz B., Khoruzhenko A., D'Onofrio M. F., Ramont L., Venteo L., Perreau C., Antonicelli F., Maquart F. X., Wegrowski Y. The small leucine-rich proteoglycan lumican inhibits melanoma progression // Exp. Cell Res.-2004.-296, N 2.-P. 294-306.

34. Breus O. S., Nemazanyy I. O., Gout I. T., Filonenko V.V., Panasyuk $G$. G. CoA Synthase influences adherence-independent growth and survival of mammalian cells in vitro // Biopolym. Cell.-2009.-25, N 5.-P. 384-389.

35. Westermark K., Nilsson M., Karlsson F. A. Effects of interleukin 1 alpha on porcine thyroid follicles in suspension culture // Acta Endocrinol. (Copenh).-1990.-122, N 4.-P. 505-512.

36. Khoruzhenko A. I., Cherednyk O. V., Filonenko V. V. Subcellular localization of S6K1 and S6K2 forms of ribosomal protein S6 kinase in primary monolayer culture of rat thyrocytes // Biopolym. Cell.-2008.-24, N 1.-P. 35-40.

37. Khoruzhenko A. I., Cherednyk O. V., Filonenko V. V. Immunohistochemical analysis of subcellular localization of S6K1 
and S6K2 forms of ribosomal protein S6 kinase in rat thyrocytes under conditions of two- and three-dimensional culture // Biopolym. Cell.-2008. 24, N 6.-P. 470-475.

38. Pomahac B., Svensjo T., Yao F., Brown H., Eriksson E. Tissue engineering of skin // Crit. Rev. Oral Biol. Med.-1998.-9, N 3.-P. 333-344.

39. Nizheradze $K$. Concanavalin A, but not glycated albumin, increases subendothelial deposition of von Willebrand factor in vitro // Endothelium.-2006.-13, N 4.-P. 245-248.

40. Ayala P., Lopez J. I., Desai T. A. Microtopographical cues in 3D attenuate fibrotic phenotype and extracellular matrix deposition: implications for tissue regeneration // Tissue Eng. Part A.-2010.-16, N 8.-P. 2519-2527.

41. Kotlarz G., Wegrowski Y., Martiny L., Declerck P. J., Bellon $G$. Enhanced expression of plasminogen activator inhibitor-1 by dedifferentiated thyrocytes // Biochem. Biophys. Res. Communs.-2002.-295, N 3.-P. 737-743.

42. Abbott A. Cell culture: biology's new dimension // Nature.2003.-424, N 6951.-P. 870-872.

43. Weaver V. M., Petersen O. W., Wang F., Larabell C. A., Briand P., Damsky C., Bissell M. J. Reversion of the malignant phenotype of human breast cells in three-dimensional culture and in vivo by integrin blocking antibodies // J. Cell. Biol.1997.-137, N 1.-P. 231-245.

44. Wang F., Weaver V. M., Petersen O. W., Larabell C. A., Dedhar S., Briand P., Lupu R., Bissell M. J. Reciprocal interactions between beta1-integrin and epidermal growth factor receptor in three-dimensional basement membrane breast cultures: a different perspective in epithelial biology // Proc. Natl Acad. Sci. USA.-1998.-95, N 25.-P. 14821-14826.

45. Overall C. M., Lopez-Otin C. Strategies for MMP inhibition in cancer: innovations for the post-trial era // Nat. Rev. Cancer.-2002.-2, N 9.-P. 657-672.

46. Wolf K., Mazo I., Leung H., Engelke K., von Andrian U. H., Deryugina E. I., Strongin A. Y., Brocker E. B., Friedl P. Compensation mechanism in tumor cell migration: mesenchymalamoeboid transition after blocking of pericellular proteolysis // J. Cell. Biol.-2003.-160, N 2.-P. 267-277.

47. Sahai E., Marshall C. J. Differing modes of tumour cell invasion have distinct requirements for Rho/ROCK signalling and extracellular proteolysis // Nat. Cell Biol.-2003.-5, N 8.P. 711-719.

48. Cukierman E., Pankov R., Stevens D. R., Yamada K. M. Taking cell-matrix adhesions to the third dimension // Science.2001.-294, N 5547.-P. 1708-1712.

49. Kim K. U., Wilson S. M., Abayasiriwardana K. S., Collins R., Fjellbirkeland L., Xu Z., Jablons D. M., Nishimura S. L., Broaddus $V$. C. A novel in vitro model of human mesothelioma for studying tumor biology and apoptotic resistance // Am. J. Respir. Cell. Mol. Biol.-2005.-33, N 6.-P. 541-548.

50. Wilson S. M., Barbone D., Yang T. M., Jablons D. M., Bueno R., Sugarbaker D. J., Nishimura S. L., Gordon G. J., Broaddus $V$. C. mTOR mediates survival signals in malignant mesothelioma grown as tumor fragment spheroids // Am. J. Respir. Cell. Mol. Biol.-2008.-39, N 5.-P. 576-583.

51. Yang T. M., Barbone D., Fennell D. A., Broaddus V. C. Bcl-2 family proteins contribute to apoptotic resistance in lung cancer multicellular spheroids // Am. J. Respir. Cell Mol. Biol.2009.-41, N 1.-P. 14-23.

52. Tomei A. A., Boschetti F., Gervaso F., Swartz M. A. 3D collagen cultures under well-defined dynamic strain: a novel strain device with a porous elastomeric support // Biotechnol. Bioeng.-2009.-103, N 1.-P. 217-225.

53. Fischbach C., Kong H. J., Hsiong S. X., Evangelista M. B., Yuen W., Mooney D. J. Cancer cell angiogenic capability is regulated by $3 \mathrm{D}$ culture and integrin engagement // Proc. Natl Acad. Sci. USA.-2009.-106, N 2.-P. 399-404.

55. Hadjipanayi E., Mudera V., Brown R. A. Guiding cell migration in 3D: a collagen matrix with graded directional stiffness // Cell Motil. Cytoskeleton.-2009.-66, N 3.-P. 121-128.

55. Roig A. I., Hight S. K., Shay J. W. Two- and three-dimensional models for risk assessment of radiation-enhanced colorectal tumorigenesis // Radiat. Res.-2009.-171, N 1.-P. 33-40.

UDC $577.25+576$

Received 05.10.10 